ledge of meteorology, and has been applied to aeronautics, being of material assistance to the fruitful use of the wind-tunnel. $\mathrm{He}$ is also a pioneer in the field of research into the conditions in solid bodies during strain, plastic deformation, fatigue, and creep. The practical character of his researches is exemplified by his work on the torsional stiffness of airscrew blades, and he has forged new links between science and engineering to their mutual advantage.

The Sir Charles Parsons Memorial of the Institution, founded in 1936, comprises the erection of a memorial in Westminster Abbey, a Parsons Memorial Library, and an annual lecture on any of the subjects in which Sir Charles Parsons was interested, for which a commemorative bronze medal is awarded. The lecturer for 1939 was Dr. H. L. Guy, who dealt with "Some Researches on Steam Turbine Nozzle Efficiency". Dr. Guy has been the chief engineer of the Mechanical Department, Metropolitan-Vickers Electrical Co., Ltd., since 1919.

\section{Colonial Policy and Scientific Research}

Notwrthstanding the preoccupation of Parliament with the grave crisis in the position of the Allies, the second reading of the Colonial Development and Welfare Bill was moved in the Commons on May 21 by Mr. Malcolm MacDonald, Secretary of State for the Colonies in the previous administration. The measure, in spite of an expression from Colonel Wedgwood of his disbelief in the post-War possibility of the financial provision which the Bill proposes, met with the general approval as to its principles from all parts of the House and was read a second time. Mr. MacDonald, in supporting his motion, asked that Parliament, by passing the Bill, should let the world mark our faith in ultimate victory, and our confidence that after the War Great Britain would still exercise vast responsibilities for the Government of colonial peoples. In the subsequent debate Sir George Schuster pointed out that there are no people in the world to whom the success of Germany would be more disastrous than those, for example, in the parts of Africa which we now administer.

That this is no exaggeration may readily be inferred from the Nazi doctrine of the treatment to be meted out to the so-called inferior races. Over against this, Britain may point with justifiable pride to what is unquestionably the most liberal and farsighted act of policy ever initiated in the history of colonial administration. Not only will the territories under the Colonial Office be relieved of a heavy burden by the remission of $£ 11,000,000$ out of their Governments' debt of $£ 15,000,000$ to the United Kingdom Exchequer, but also the provision of funds for development and research should ensure that the way to their future prosperity is laid open to them. The provision for research should make it possible to mobilize every resource of science in their service, especially under the leadership of Lord Moyne and Lord Hailey, who, as Mr. MacDonald announced, will act as chairman of the Advisory Committees on Development and Research respectively when these are appointed.

\section{Food and the Housewife}

IN a lecture on May. 28 at the Royal Institution in the series "The Nation's Larder", Prof. V. H. Mottram pointed out that the housewife who takes an intelligent interest in feeding her family well and according to modern dietetic principles needs some simplified scheme of the facts of dietetics upon which to work. Energy foods are not usually useful for body-building and body-protecting purposes; bodybuilding foods are often poor as energy and protective foods. Protective foods often have little energy or body-building power. Therefore the foods of one class must not be replaced by those from another class. For example, there is a danger that because we have less meat to eat we may replace it with bread. We must replace it with milk, cheese or fish. Those foods (for example, milk, cheese, fat fish) which combine the functions of two or more classes of foods, are much the most precious foods in diet. The safest rule is first to make sure of the protective foods (dairy foods, greengroceries and the fat fish), add some meat and bacon, and then to satisfy appetite with bread and groceries. Increased consumption of milk, cheese, green vegetables, salad vegetables, fruits and fish such as herrings, sprats, mackerel and salmon (fresh or tinned) is desirable. If this is achieved, it is probable that the energy and even the body-building values of foods will look after themselves. The climate and soil of Great Britain are particularly well adapted to producing protective foods.

\section{Malaria as an Occupational Disease}

Is his inaugural thesis (Thèse de Paris, No. 707 ; 1939) Dr. J. C. Lévy states that malaria is regarded as an occupational disease, for which appropriate compensation should be made, in certain countries, particularly North America (especially the States of Wisconsin and Illinois), Brazil, Spain and Italy, where its frequency as an occupational disease has given rise to special legislation. In France, on the other hand, there are no legislative measures recognizing malaria as an occupational disease, and compensation for contracting it is allowed only in the case of soldiers, sailors and airmen. Dr. Lévy therefore demands that malaria should be added to the list of occupational diseases in France for the following reasons : first, to repair the material damage to which a variety of workers are liable, namely, colonials and labourers in the veldt or canals, and secondly, for the adoption of additional prophylactic measures in conditions and localities where the work involves the risk of contracting malaria.

\section{The Nature of Virus}

Dr. Thomas M. Rrvers discussed the possibilities that viruses represent a transition between living and non-living matter, at a meeting of the New York Academy of Medicine on March 29. A report of the meeting issued by Science Service mentions that the discovery of bacteria was formerly held by some men of science to indicate the origin of life in the world. Many workers now believe this to be the case 